\title{
The Impact of Entrepreneurship Initiatives in Enhancing Creativity and Innovation
}

\author{
Mohammad Ali Al Qudah ${ }^{1}$ \\ ${ }^{1}$ Police Science Academy in Sharjah, United Arab Emirates \\ Correspondence: Mohammad Ali Al Qudah, Police Science Academy in Sharjah, United Arab Emirates. E-mail: \\ qudah962@gmail.com
}

Received: May 1, 2018

Accepted: May 30, 2018

Online Published: June 15, 2018

doi:10.5539/ijbm.v13n7p157

URL: https://doi.org/10.5539/ijbm.v13n7p157

\begin{abstract}
The current study aimed at understanding the influence of the Entrepreneurship Initiatives on creativity and innovation in business. It was hypothesized that the dimensions of entrepreneurship including (Strategies, Technology, Resources, Management Support and Culture) positively influences the creativity and innovation of business within the Jordanian environment. The sample of the study was derived from a telecommunication company which included (34) individuals from the high and the middle management.

The results of the study indicated that there is a positive influence of entrepreneurship initiatives on creativity and innovation within organizations and enterprises. The most influential variables appeared to be (Culture, Management Support, Technology, Strategies and Resources) respectively. The most influential variable appeared to be the culture. The study recommended nourishing the culture within the Jordanian business environment in a way that makes more welcoming to any Entrepreneurship Initiatives.
\end{abstract}

Keywords: entrepreneurship, dimensions of entrepreneurship, creativity, innovation

\section{Introduction}

There has been recently an increased interest in the idea of entrepreneurship due to the technological development and the outstanding performance that the private sector managed to prove in enhancing the economic. According to Taylor (2007) the concept of entrepreneurship is not new, it is not the product of the $21^{\text {st }}$ century, it has been there ever since the $19^{\text {th }}$ century referring to the status where one is welling to launch a certain project and they are aware of the uncertain consequences that may appear.

What has made the idea of entrepreneurship very popular is its ability in changing the scheme of the economic status of the country, not to mention the new ideas that it may bring, in addition to the work opportunities that it may bring to others. However, Taylor (2007) stated that entrepreneurship is the level if being able to plan for new projects and ideas, organize it, deal with it creatively and be aware of the risks and jeopardies that may involve them in the future.

\subsection{Problem Statement}

Entrepreneurship in the Middle East now is being the center of attention given that it has proved its ability to operate businesses, increase the performance and insure an income to the economy and working opportunities for individuals in the country. Many factors may have a role in either increasing or decreasing the awareness and productivity of Entrepreneurship Initiatives within the Arab world. However, the current study seeks to examine the influence of a set of variables on creativity and innovation in Entrepreneurship Initiatives including (Strategies, Technology, Resources, Management Support and Culture) within the telecommunication companies in Jordan.

\subsection{Questions and Hypotheses}

Main hypothesis:

Entrepreneurship positively enhances innovation and creativity and business.

Sub-hypotheses:

$\mathrm{H} 1$ : There is a statistically significant influence of strategies on innovation and creativity in business. 
$\mathrm{H} 2$ : There is a statistically significant influence of technology on innovation and creativity in business.

H3: There is a statistically significant influence of resources on innovation and creativity in business.

H4: There is a statistically significant influence of management support on innovation and creativity in business.

H5: There is a statistically significant influence of culture on innovation and creativity in business.

Dimensions of Entrepreneurship

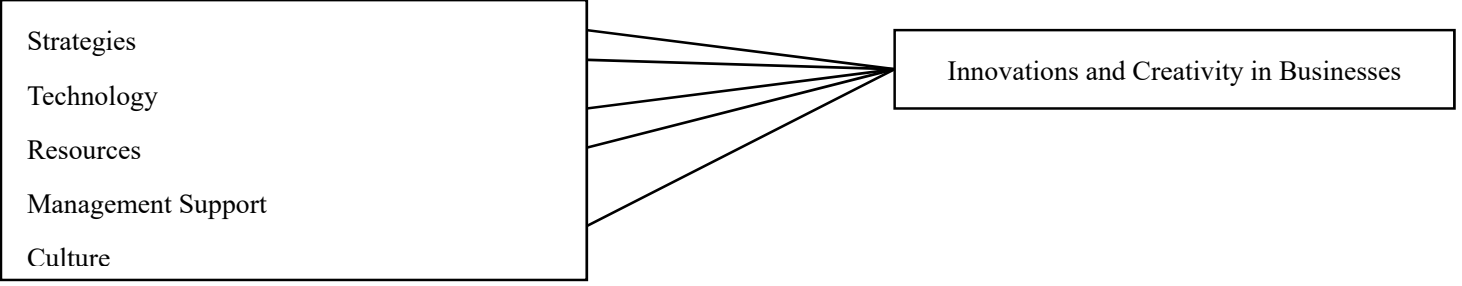

Figure 1. Model of the study

\section{Literature Review}

\subsection{Definition of Entrepreneurship}

Entrepreneurship is a multidimensional concept encompassing various dimensions (Low, 2001). This multidimensional nature of entrepreneurship has made researchers to conceptualize in in many different ways from different perspective. It is also worth recognizing that the entrepreneurship as a concept has been evolving over years and that its conceptualization has also been changing. For example, in the middle ages, entrepreneurship was used to refer to an individual's ability to manage large production projects (Padilla and Cachanosky, 2016). This way, the focus was on the individual's ability to manage the projects using the available resources but not on the ability of individual to take risks. Accordingly, a typical entrepreneur as approached from this middle ages, was a cleric or an individual who was in-charge of managing great architectural works and fortification $f$ cathedrals, abbeys and public buildings. This perspective changed in 17th century when people started connecting entrepreneurship with risks. As conceptualized during this period, an entrepreneur was an individual contracted by the government to supply stipulated product or perform a service, and through this contractual agreement, he earned a profit or loss. This was in line with Richard Cantillion's 17th century theory that so an entrepreneur as a risk taker who could buy products at certain price and sell them at a different but uncertain price. In line with this view, farmers, craftsmen, merchants and other sole proprietors exemplified entrepreneurs during this age. Later in 18th century, entrepreneurs were seen as venture capitalists (Rahatullah Khan, 2013). This view slightly changed in 19th and 20th century as entrepreneurship was largely viewed from the economic perspective and not distinguished from management. Accordingly, an entrepreneur was identified as an individual who operated and managed a business for personal gains and one who paid prices for materials used by the enterprise; paid for the use of the land and for capital, as well as for personal services employed. An entrepreneur was also seen as a person who could contribute personal initiative, ingenuity, and skill in planning, administering and organizing the enterprise. This individual was could assume the chance of gaining a profit or incurring a loss consequent to uncontrollable and unforeseen circumstances (Bridge, 2017). The element of innovation was added to the definition of entrepreneurship in 20th and 21st century. Today, entrepreneurs are seen as individuals with the ability to revolutionize patterns of production through exploiting an invention (Piti, 2010). Others (e.g., Pleter, 2005) see an entrepreneur as a business person who start (built), develop and manage a business enterprise risking money, effort and time. Similarly, Baron and Henry (2010) sees entrepreneurship as referring to the individual who utilizes him qualities, including risk taking, innovation, creativity, and ability to manage and plan activities to implement an ideas with the aim of fulfilling a certain objective.

\subsection{Dimensions of Entrepreneurship}

Entrepreneurship is neither an economic function nor a set of personality traits. Rather, entrepreneurship is a pattern of managerial behavior and an approach to management that involves pursuing opportunities without regard to risks involved and resources currently controlled. This description of entrepreneurship can be refined by using five important dimensions of business practice: resources, technology, strategy, culture, and 
management support. These dimensions are the critical dimensions of entrepreneurship. These dimensions are defined by looking at a range of behaviours. The argument is that entrepreneurial management is a range behaviours that fall at two ends of the spectrum. At one extreme, an entrepreneur is seen as "promoter" who is confident of his ability to seize opportunities presented regardless of the available resources. At the other extreme, an entrepreneur is seen as a "trustee" who puts emphasis on the efficient utilization of the available resources.

\subsection{Strategies}

As described by Kuratko, and Audretsch (2009) entrepreneurship involves formulation of strategic. Karlsson, Friis, and Paulsson (2004) opined that as promoters, entrepreneurs are strategy driven and opportunity driven. They are driven by the perceptions of the existing opportunities to generate and implement an idea and utilize resources they control but not constrained by resources they have at hand. Being strategy oriented, entrepreneurs are opportunistic, innovative and creative. They are pushed by two key factors to create new strategies: diminishing opportunity streams; rapid change in technology. These individuals are said to show commitment to opportunity by pursuing it rather than merely identifying it. As promoters, entrepreneurs demonstrate the willingness to act within a short time frame in chasing for the opportunity. According to Kuratko, and Audretsch (2009) it is this willingness to get out and in quickly that has earned them the reputation as gamblers. They are known to risk take as they create strategy and learn about the territory they operate in.

\subsection{Resources}

Multi-stage commitment of resource is another characteristic of good entrepreneurship. As noted by Bryman, and Bell (2003), entrepreneurship is about identifying the resources that are needed to pursue the identify opportunity. Bryman, and Bell (2003) also noted that entrepreneurship involve striving to balance the tension between the quantity of resources committed to an enterprise and the potential return. Martin, and Osberg (2007) added that entrepreneurs often seek to minimize resource set in an attempt to maximize the creation of value. According to Martin, and Osberg (2007) several factors push the process of committing resources towards the entrepreneurial domain. These factors are identified as social needs; international demands; lack of long-term control; lack of predictable resource needs; personal risk reduction; formal planning systems; capital allocation systems; incentive compensation; and managerial turnover.

\subsection{Technology}

Technology is the key driver of entrepreneurship and that it is the driving force behind societies and national economies. It is argued that technology-driven entrepreneurships is the engine of job creation, economic growth, productivity growth, and economic growth (Martin, \& Osberg, 2007; Lazear, 2005). The idea is that technology is the driving force for entrepreneurship ventures and acts as a powerful force to shape entrepreneurs' mindsets, values and behavior. According to Audretsch (2004) each technology innovation comes with a wave of new entrepreneurs and new start-ups. Audretsch (2004) further noted that entrepreneurial activity acts through the availability and transmission of technology and innovative ideas and the existence of infrastructure that supports entrepreneurial efforts.

\subsection{Management Support}

Any organization's management play an important role I nurturing and entrepreneurs. According to Dess (2003) the supervision style and support of leaders or managers facilitate corporate entrepreneurship. Dess (2003) argued that organizations that fail to innovate by supporting entrepreneurship may face inevitable disruption. Supporting Dess (2003), Sumo (2010) noted that one way organizations can avoid creative destruction and remain on growth path is by supporting and nurturing entrepreneurial environment (i.e., cultivating entrepreneurship in the firm) in order to secure growth, survival and competitiveness. Other researchers (e.g., Baer \& Frese, 2003; Hunter, Bedell \& Mumford, 2007) have supported the view that organizational support is a driver to entrepreneurship. According to Baer and Frese (2003) an organization can support entrepreneurship by ensuring that resources are available for individuals to implement new ideas, and supporting discussions on new ideas, rewarding goods ideas, and top management showing commitment to entrepreneurship.

\subsection{Culture}

As revealed in the Institutional Economic Theory culture is one of the informal factor that influence entrepreneurship. Culture combines elements that characterize the society, and determine behavior of people in the society (House, Quigley, \& De Luque, 2010). According to House and Javidan (2004) culture influences the societal entrepreneurial activity by influencing corporate behavior of individuals. It influences their behavior towards the creation of businesses and thus encourage entrepreneurship (Gurel et al., 2010; Li, 2007). Social institutions especially norms and culture have also been identified as dimensions of entrepreneurship because of 
their influence on the way individuals view social role of entrepreneurs and how individuals develop the desire to become entrepreneurs. It has been revealed that entrepreneurial behavior is sensitive to the social environment and that it responds to set of cues from such an environment (Hunt, \& Levie, 2003).

\subsection{Arabic Entrepreneurship Initiatives}

Countries in the Arab world have recognized the value and importance of entrepreneurship in tackling youth unemployment. They have realized the value of entrepreneurship in promoting inclusive economic growth and are increasingly supporting and initiating programs that support entrepreneurship. To this effect, many initiatives have existed in the Arab world to support Youths and women. There are several notable Arabic entrepreneurship initiatives. Examples of Arabic entrepreneurship initiatives targeted at empowering women and youth include Roudha center, Glowork, Trochet, Women in Technology (WIT), How Women Work, Diva Events \& Media, Artistry Egypt among others. Roudha Center is a Qatar based one-stop-shop for women entrepreneurs focusing on fueling the Qatar economic through offering a holistic approach to empowering women by equipping them with knowledge, skills and confidence they required to succeed as entrepreneurs. Women's Digital League is digital service firms owned by Pakistani women aimed at empowering women in the remote areas of the country. Glowork is a social enterprise based in Saudi Arabia aimed at driving the participation of women in the workforce. Trochet is project aimed at uplifting women out poverty. This project focuses on collecting recycling plastic bags and sending them to women from rural areas to crotchet and knit into creative products and designs like bean-bag chairs, new bags and coasters. Glowark was founded by Khalid Alkhudair as a website dedicated to recruitment of women in the Gulf. It empowers women in the Gulf and increases the diversity of Saudi Arabia workforce. Hamzet Wasel is a Jordan based social venture that specializes in reviving and enriching cultural and social fabric of urban communities in Amman. It incubates and invests in innovative ideas that foster social change. Souktel is a Palestine mobile phone-based services that make use of SMS technology to connect aid agencies with individuals who require help and link people with jobs. Social Media Exchange is a Lebanon based social enterprise that offer strategic social media consulting and training to social businesses and NGOs in Lebanon. It focuses on developing custom social media training people in Lebanon and providing social-media-enable coverage for events. They focus on three key areas: raising awareness about participatory media and social media, helping organizations create collaborative strategies to help increase internet access and promote the inclusion of social media into organizations' programs

\subsection{Creativity and Innovation in Businesses}

Innovation and creativity are critical skills needed to succeed in a business one needs creativity insights in order to create a solution to a management problem. Innovation is a product of creativity, which is defined as an individual's ability to create new and unique ideas. Innovation is typically the implementation of creativity to find a solution to an issue (Mcbeth, \& Rimac, 2004). It entails thinking creatively about an already existing issue. It is the introduction of new solution, new idea, product or process that lead to improved effectiveness or efficiency of a system. It drives innovation as it enables an individual to approach a problem from a different perspective. It involves restructuring and breaking down our knowledge about an issues to gain new insights. Its two key aspects are people and process (Mcbeth, \& Rimac, 2004). It is process-oriented and aimed at helping an individual or organization find solution to a problem (Coster, 2004). People are the resource that offer the solution. They adapt or formulate innovative solutions to a problem (Mcbeth, \& Rimac, 2004). Using this innovative approach, creative people discovers avenues of solution and problems, approaches problems from unique angles, and formulates assumptions related to the problem (Kurato, \& Hodgetts, 2007).

Business creativity keeps business thriving and alive. Creative and innovative business succeeds as stimulating creative problem solving and creativity will (Nnadi, 2014):

- $\quad$ Propel innovation forward

- Lead to improvement in solving problems

- Increased productivity

- Give a business the competitive edge

Innovation is a strategic lever for business transformation, change, profitability, management, and overall sustainability. It is also a lever that empowers, engages, and enables individuals to deliver profound system, culture, people, product, and process change. It leads to increased organizational competitiveness, reach, engagement, faster business growth, and increased business value (Nnadi, 2014).

\subsection{The Role of Entrepreneurship Initiatives in Increasing Creativity and Innovation}


Innovation is the key function of entrepreneurship. Nnadi (2014) sees innovation as a means via which entrepreneurs endow existing resources with better potential to create wealth and a way to create new wealth-producing resources. Innovation is the perceptual and conceptual and would-be entrepreneurs ask, listen and go out and seek for it. They look at people and at figure and analytically create an innovation that satisfies the opportunity. Elsewhere, Schumpeterian views innovation as a criterion of entrepreneurship whose defining characteristics is doing new things that have not been done. This new way is a creative response to situations that had three key characteristics. First characteristics are that the creative response can never be understood practically. Secondly, it shapes the course of subsequent events and outcomes. Thirdly, it deals with the quality of personnel.

Entrepreneurship and creativity and innovation form a feedback loop in that entrepreneurship breeds innovation and creativity and the vice versa holds true. According to Audretsch (2004), innovation entails putting into practice inventions. It encompasses developing new sources of supply, new processes, new products, and the establishment and exploitation of new markets, as well as finding new ways of organizing business. On the contrary, entrepreneurship has been identified as a concept encompasses the exploitation and discovery of opportunities, and it is thus widely considered the best approach to increasing innovation and creativity. In fact, () believes entrepreneurship as a concept is all about creativity and innovation suggesting that creativity and innovation can be fostered through entrepreneurial initiatives. To support his argument; Bryman and Bell (2003) identified three strands of literature that argue for support the view that entrepreneurship initiatives may support innovation and creativity. The first stand of literature identifies entrepreneurship as a creative and dynamic feature of actors, namely owners, and managers of small enterprises or department heads. This strand does not tie together innovation and entrepreneurship. The second strand of literature creates a distinction between non-innovative and innovative firms. The third and last strand focuses on the owner-operate firms and makes a distinction between less innovative entrepreneurship and innovative entrepreneurship (Klein, 2008).

\section{Methodology}

The current study was quantitative in its nature; the researcher depended on numerical data in order to be able to understand the influence of the variables on the main independent variable. In that sense, the researcher has chosen the questionnaire to be the tool of the study, the questionnaire was divided into two parts; the first is presented the demographic variables of the study while the later presented the paragraphs of the questionnaire based on liker 5 scale.

The sample of the study consisted of (40) individuals from the high and middle management within the telecommunication companies in Jordan. The questionnaire was self-administered and it was distributed on the sample of the study. The researcher was able to collect (34) properly filled questionnaires forming $85 \%$ of the total sample which a percentage that is statistically accepted.

\section{Results}

The current section presented the statistical analysis which took place on the gathered data of the study. The section is divided into two parts; the first presented the characteristics of the sample of the study, while the other part presented the testing of the hypotheses of the study according to the model which was presented earlier.

A) Characteristics of the sample of the study

Table 1. Characteristics of the sample according to educational level

\begin{tabular}{llllll}
\hline & & Frequency & Percent & Valid Percent & Cumulative Percent \\
\hline Valid & Bachelors & 4 & 11.8 & 11.8 & 11.8 \\
& Masters & 25 & 73.5 & 73.5 & 85.3 \\
& PhD & 5 & 14.7 & 14.7 & 100.0 \\
& Total & 34 & 100.0 & 100.0 & \\
\hline
\end{tabular}

According to the table above it was found out that $73.5 \%$ of the sample were individuals who held the master's degree with a frequency of 25; followed by individuals who held a $\mathrm{PhD} 14.7 \%$ and a frequency of 5 . 
Table 2. Characteristics of the sample according to experience

\begin{tabular}{llllll}
\hline & & Frequency & Percent & Valid Percent & Cumulative Percent \\
\hline Valid & $2-5$ & 9 & 26.5 & 26.5 & 26.5 \\
& $6-9$ & 8 & 23.5 & 23.5 & 50.0 \\
& $10-13$ & 10 & 29.4 & 29.4 & 79.4 \\
& +14 & 7 & 20.6 & 20.6 & 100.0 \\
& Total & 34 & 100.0 & 100.0 & \\
\hline
\end{tabular}

According to table 2 it was found out that $29.4 \%$ of the sample were individuals who an experience of $10-13$ years with a frequency of 10 ; followed by individuals who had an experience of $26.5 \%$ and a frequency of 9 . The results of this section appeared to be narrow and the differences were not wide.

Table 3. Descriptive results of variables

\begin{tabular}{llllll}
\hline \multicolumn{2}{l}{ Descriptive Statistics } & & & \\
& $\mathrm{N}$ & Minimum & Maximum & Mean & Std. Deviation \\
\hline Innovations & 34 & 2.00 & 5.00 & 4.0662 & .69170 \\
Strategies & 34 & 3.00 & 5.00 & 4.1544 & .55737 \\
Technology & 34 & 2.67 & 5.00 & 4.1667 & .62090 \\
Resources & 34 & 1.25 & 5.00 & 3.9338 & .86451 \\
Management & 34 & 2.33 & 5.00 & 3.7941 & .69153 \\
Culture & 34 & 2.75 & 5.00 & 4.0588 & .70458 \\
\hline
\end{tabular}

Examining the above table 3, it can be seen that there is a positive attitude from participants towards the above questions. This appeared through the mean of the paragraphs which scored higher than 3.00 referring to the paragraph as a good indicator.

Table 4. Descriptive statistics of questionnaire paragraphs

\begin{tabular}{|c|c|c|c|c|c|}
\hline & $\mathrm{N}$ & Minimum & Maximum & Mean & Std. Deviation \\
\hline \multicolumn{6}{|l|}{ Innovations and Creativity in Businesses } \\
\hline Innovations and Creativity promotes a successful business & 34 & 1 & 5 & 3.68 & 1.093 \\
\hline It is important for individuals to be innovative and creative in business & 34 & 2 & 5 & 4.29 & .799 \\
\hline Good business environment supports creativity and innovation & 34 & 2 & 5 & 4.09 & .866 \\
\hline Good chances supports creativity and innovation & 34 & 2 & 5 & 4.21 & 687 \\
\hline \multicolumn{6}{|l|}{ Strategies } \\
\hline Well-built strategies can create a better entrepreneurship & 34 & 2 & 5 & 4.24 & .890 \\
\hline Planned strategies can help entrepreneurship initiatives & 34 & 3 & 5 & 4.03 & .577 \\
\hline A strategic infrastructure can promote a good entrepreneurship initiatives & 34 & 3 & 5 & 4.21 & .729 \\
\hline Most entrepreneurship initiatives are based on strategies and planning & 34 & 1 & 5 & 4.15 & 1.105 \\
\hline \multicolumn{6}{|l|}{ Technology } \\
\hline entrepreneurship derive its strength from technology & 34 & 3 & 5 & 4.38 & .551 \\
\hline Technology is a powerful entrepreneurship initiatives support & 34 & 2 & 5 & 4.18 & .758 \\
\hline A good technological infrastructure can promote entrepreneurship initiatives & 34 & 1 & 5 & 3.94 & 1.013 \\
\hline \multicolumn{6}{|l|}{ Resources } \\
\hline Resource are important to entrepreneurship initiatives & 34 & 1 & 5 & 3.74 & 1.024 \\
\hline Employees are part of resources in entrepreneurship initiatives & 34 & 1 & 5 & 4.21 & .946 \\
\hline Training is a crucial part in entrepreneurship initiatives & 34 & 1 & 5 & 3.82 & .968 \\
\hline $\begin{array}{l}\text { It is important to be aware of the meaning of entrepreneurship before } \\
\text { embracing it }\end{array}$ & 34 & 2 & 5 & 3.97 & 1.000 \\
\hline \multicolumn{6}{|l|}{ Management Support } \\
\hline The manage is the first support of entrepreneurship initiatives & 34 & 1 & 5 & 4.06 & 1.013 \\
\hline entrepreneurship initiatives starts within the managerial environment & 34 & 3 & 5 & 3.65 & .849 \\
\hline $\begin{array}{l}\text { A manager has to be aware of entrepreneurship initiatives meaning and benefits } \\
\text { Culture }\end{array}$ & 34 & 3 & 5 & 3.68 & .768 \\
\hline
\end{tabular}




\begin{tabular}{|c|c|c|c|c|c|}
\hline $\begin{array}{l}\text { The culture and the environment are the bases of good entrepreneurship } \\
\text { initiatives }\end{array}$ & 34 & 3 & 5 & 4.24 & .741 \\
\hline There is always a good entrepreneurship initiatives in a good culture & 34 & 2 & 5 & 4.03 & .904 \\
\hline A culture can support innovation and creativity & 34 & 2 & 5 & 3.85 & .892 \\
\hline The culture is the first incubator of entrepreneurship initiatives & 34 & 2 & 5 & 4.12 & .844 \\
\hline
\end{tabular}

Examining the above table 4, it can be seen that there is a positive attitude from participants towards the above questions. This appeared through the mean of the paragraphs which scored higher than 3.00 referring to the paragraph as a good indicator.

\subsection{Reliability Test}

A reliability test was carried out using Cronbachs' alpha, The result showed a value of (0.943) for the all items as well as alpha for each variable is greater than accepted percent 0.60 , which is a reasonable value indicating the tool consistency that enhanced its use for the study

Main hypothesis: Entrepreneurship positively enhances innovation and creativity and business.

Table 5. Regression analysis (model summary)

\begin{tabular}{lllll}
\hline Model & R & R Square & Adjusted R Square & Std. Error of the Estimate \\
1 & $.785^{\mathrm{a}}$ & .617 & .548 & .46480 \\
\hline
\end{tabular}

Table 6. ANOVA

\begin{tabular}{lllllll}
\hline Model & Sum of Squares & df & Mean Square & F & Sig. \\
\hline 1 & Regression & 9.740 & 5 & 1.948 & 9.017 & $.000^{\mathrm{b}}$ \\
& Residual & 6.049 & 28 & .216 & & \\
\multicolumn{1}{c}{ Total } & 15.789 & 33 & & & \\
\hline
\end{tabular}

Table 7a. Coefficients

\begin{tabular}{|c|c|c|c|c|c|c|}
\hline \multirow{2}{*}{\multicolumn{2}{|c|}{ Model }} & \multicolumn{2}{|c|}{ Unstandardized Coefficients } & \multirow{2}{*}{$\begin{array}{l}\text { Standardized Coefficients } \\
\text { Beta }\end{array}$} & \multirow[t]{2}{*}{$\mathrm{t}$} & \multirow[t]{2}{*}{ Sig. } \\
\hline & & B & Std. Error & & & \\
\hline \multirow[t]{6}{*}{1} & (Constant) & .371 & .669 & & .555 & .583 \\
\hline & Strategies & .757 & .252 & .610 & 3.004 & .006 \\
\hline & Technology & .370 & .221 & .332 & 1.674 & .105 \\
\hline & Resources & .414 & .171 & .518 & 2.427 & .022 \\
\hline & Management & -.171 & .185 & -.171 & -.924 & .363 \\
\hline & Culture & -.486 & .269 & -.495 & -1.806 & .082 \\
\hline
\end{tabular}

Multiple regression is used to test this hypothesis, It is found that $\mathrm{R}(0.785)$ is the correlation of the independent variables and the dependent variable. Also it is found that the F value of (9.017) is significant at (0.05) level. Thus, Entrepreneurship positively enhances innovation and creativity and business.

H1: There is a statistically significant influence of strategies on innovation and creativity in business.

Table 7b. Model summary

\begin{tabular}{lllll}
\hline Model & R & R Square & Adjusted R Square & Std. Error of the Estimate \\
\hline 1 & $.675^{\text {a }}$ & .456 & .439 & .51814 \\
\hline
\end{tabular}

Table 7c. ANOVA

\begin{tabular}{lllllll}
\hline \multicolumn{2}{l}{ Model } & Sum of Squares & df & Mean Square & F & Sig. \\
\hline 1 & Regression & 7.198 & 1 & 7.198 & 26.810 & $.000^{\mathrm{b}}$ \\
& Residual & 8.591 & 32 & .268 & & \\
\multicolumn{1}{l}{ Total } & 15.789 & 33 & & & \\
\hline
\end{tabular}


Table 7d. Coefficients

\begin{tabular}{|c|c|c|c|c|c|c|}
\hline \multirow{2}{*}{\multicolumn{2}{|c|}{ Model }} & \multicolumn{2}{|c|}{ Unstandardized Coefficients } & \multirow{2}{*}{$\begin{array}{l}\text { Standardized Coefficients } \\
\text { Beta }\end{array}$} & \multirow[t]{2}{*}{$\mathrm{t}$} & \multirow[t]{2}{*}{ Sig. } \\
\hline & & $\mathrm{B}$ & Std. Error & & & \\
\hline \multirow[t]{2}{*}{1} & (Constant) & .585 & .678 & & .863 & .395 \\
\hline & Strategies & .838 & .162 & .675 & 5.178 & .000 \\
\hline
\end{tabular}

Linear regression is used to test this hypothesis; it is found that $\mathrm{R}(0.675)$ is the correlation of the independent variable and the dependent variable. Also it is found that the F value of (26.81) is significant at (0.05) level. Thus, there is a statistically significant influence of strategies on innovation and creativity in business.

$\mathrm{H} 2$ : There is a statistically significant influence of technology on innovation and creativity in business.

Table 8. Model summary

\begin{tabular}{lllll}
\hline Model & R & R Square & Adjusted R Square & Std. Error of the Estimate \\
\hline 1 & $.632^{\mathrm{a}}$ & .400 & .381 & .54431 \\
\hline
\end{tabular}

Table 9. ANOVA

\begin{tabular}{lllllll}
\hline \multicolumn{2}{l}{ Model } & Sum of Squares & df & Mean Square & F & Sig. \\
\hline 1 & Regression & 6.308 & 1 & 6.308 & 21.291 & $.000^{\mathrm{b}}$ \\
& Residual & 9.481 & 32 & .296 & & \\
\multicolumn{1}{l}{ Total } & 15.789 & 33 & & & \\
\hline
\end{tabular}

Table 10. Coefficients

\begin{tabular}{lllllll}
\hline \multirow{2}{*}{ Model } & \multicolumn{2}{l}{ Unstandardized Coefficients } & \multicolumn{2}{l}{ Standardized Coefficients } & $\mathrm{t}$ & \multirow{2}{*}{ Sig. } \\
& $\mathrm{B}$ & Std. Error & Beta & & \\
\hline 1 & (Constant) & 1.132 & .643 & & 1.762 & .088 \\
& Technology & .704 & .153 & .632 & 4.614 & .000 \\
\hline
\end{tabular}

Linear regression is used to test this hypothesis; it is found that $\mathrm{R}(0.632)$ is the correlation of the independent variable and the dependent variable. Also it is found that the F value of (21.291) is significant at (0.05) level. Thus, there is a statistically significant influence of technology on innovation and creativity in business.

H3: There is a statistically significant influence of resources on innovation and creativity in business.

Table 11. Model summary

\begin{tabular}{lllll}
\hline Model & $\mathrm{R}$ & R Square & Adjusted R Square & $\begin{array}{l}\text { Std. Error of the } \\
\text { Estimate }\end{array}$ \\
\hline 1 & $.647^{\mathrm{a}}$ & .419 & .401 & .53539 \\
\hline
\end{tabular}

Table 12. ANOVA

\begin{tabular}{lllllll}
\hline \multicolumn{2}{l}{ Model } & Sum of Squares & df & Mean Square & $\mathrm{F}$ & Sig. \\
\hline 1 & Regression & 6.616 & 1 & 6.616 & 23.080 & $.000^{\mathrm{b}}$ \\
& Residual & 9.173 & 32 & .287 & & \\
\multicolumn{1}{l}{ Total } & 15.789 & 33 & & & \\
\hline
\end{tabular}

Table 13. Coefficients

\begin{tabular}{lllllll}
\hline \multirow{2}{*}{ Model } & \multicolumn{2}{l}{ Unstandardized Coefficients } & \multicolumn{2}{l}{ Standardized Coefficients } & $\mathrm{t}$ & \multirow{2}{*}{ Sig. } \\
& & $\mathrm{B}$ & Std. Error & Beta & & \\
\hline 1 & (Constant) & 2.029 & .434 & & 4.675 & .000 \\
& Resources & .518 & .108 & .647 & 4.804 & .000 \\
\hline
\end{tabular}


Linear regression is used to test this hypothesis; it is found that $\mathrm{R}(0.647)$ is the correlation of the independent variable and the dependent variable. Also it is found that the F value of (23.08) is significant at (0.05) level. Thus, there is a statistically significant influence of resources on innovation and creativity in business.

H4: There is a statistically significant influence of management support on innovation and creativity in business.

Table 14a. Model Summary

\begin{tabular}{lllll}
\hline Model & R & R Square & Adjusted R Square & Std. Error of the Estimate \\
\hline 1 & $.415^{\text {a }}$ & .172 & .146 & .63916 \\
\hline
\end{tabular}

Table 14b. ANOVA

\begin{tabular}{|c|c|c|c|c|c|c|}
\hline \multicolumn{2}{|c|}{ Model } & \multirow{2}{*}{$\begin{array}{l}\text { Sum of Squares } \\
2.716\end{array}$} & \multirow{2}{*}{$\frac{\mathrm{df}}{1}$} & \multirow{2}{*}{$\begin{array}{l}\text { Mean Square } \\
2.716\end{array}$} & \multirow{2}{*}{$\begin{array}{l}\mathrm{F} \\
6.648\end{array}$} & \multirow{2}{*}{$\frac{\text { Sig. }}{.015^{\mathrm{b}}}$} \\
\hline 1 & Regression & & & & & \\
\hline & Residual & 13.073 & 32 & .409 & & \\
\hline & Total & 15.789 & 33 & & & \\
\hline
\end{tabular}

Table 14c. Coefficients

\begin{tabular}{|c|c|c|c|c|c|c|}
\hline \multicolumn{7}{|c|}{ Coefficients $^{\mathrm{a}}$} \\
\hline \multirow{2}{*}{\multicolumn{2}{|c|}{ Model }} & \multicolumn{2}{|c|}{ Unstandardized Coefficients } & \multirow{2}{*}{$\begin{array}{l}\text { Standardized Coefficients } \\
\text { Beta }\end{array}$} & \multirow[t]{2}{*}{$\mathrm{t}$} & \multirow[t]{2}{*}{ Sig. } \\
\hline & & B & Std. Error & & & \\
\hline \multirow[t]{2}{*}{1} & (Constant) & 2.492 & .620 & & 4.018 & .000 \\
\hline & Management & .415 & .161 & .415 & 2.578 & .015 \\
\hline
\end{tabular}

Linear regression is used to test this hypothesis; It is found that $\mathrm{R}(0.415)$ is the correlation of the independent variable and the dependent variable. Also it is found that the F value of (6.648) is significant at (0.05) level. Thus, there is a statistically significant influence of management support on innovation and creativity in business.

H5: There is a statistically significant influence of culture on innovation and creativity in business.

Table 15. Model summary

\begin{tabular}{lllll}
\hline Model & R & R Square & Adjusted R Square & Std. Error of the Estimate \\
\hline 1 & $.544^{\mathrm{a}}$ & .296 & .273 & .58957 \\
\hline
\end{tabular}

Table 16. ANOVA

\begin{tabular}{lllllll}
\hline Model & Sum of Squares & df & Mean Square & F & Sig. \\
\hline 1 & Regression & 4.666 & 1 & 4.666 & 13.423 & $.001^{\mathrm{b}}$ \\
& Residual & 11.123 & 32 & .348 & & \\
\multicolumn{1}{l}{ Total } & 15.789 & 33 & & & \\
\hline
\end{tabular}

Table 17. Coefficients

\begin{tabular}{lllllll}
\hline \multirow{2}{*}{ Model } & \multicolumn{2}{l}{ Unstandardized Coefficients } & \multicolumn{2}{l}{$\begin{array}{l}\text { Standardized Coefficients } \\
\text { Beta }\end{array}$} & t & \multirow{2}{*}{ Sig. } \\
& & $\mathrm{B}$ & Std. Error & Beta & & \\
\hline 1 & (Constant) & 1.900 & .600 & & 3.168 & .003 \\
& Culture & .534 & .146 & .544 & 3.664 & .001 \\
\hline
\end{tabular}

Linear regression is used to test this hypothesis; it is found that $\mathrm{R}(0.544)$ is the correlation of the independent variable and the dependent variable. Also it is found that the F value of (13.423) is significant at (0.05) level. Thus, there is a statistically significant influence of culture on innovation and creativity in business

\section{Discussion}

According to the results of the statistical analysis of the study; it appeared that there is a positive influence of Entrepreneurship Initiatives on creativity and innovation. The results of the study indicated an influence of all 
the taken variables. In other meaning, it was found out that all the given variables of the study under the umbrella of Entrepreneurship Initiatives had an influence on creativity and innovation it included (Strategies, Technology, Resources, Management Support, and Culture). The results of the study rhymed with what came along with Uslu (2015) referring to culture, resource management and technology as one of the most influential aspects on the concept of entrepreneurship. The author also added that the development culture portrays the new eco-framework in the business fields and creation logic. The contrasts between the nations and areas regarding administration, science, building, innovation and work quality have turned into the components that clarify the multifaceted nature elements of the 21st century. Subsequently; expanding the universal focused energy of the nearby firms in the structure of local improvement legislative issues, enhancing business enterprise and development limit in neighborhood very essential in this century. In this procedure key human asset administration (SHRM) is a basic movement for organizations. A few vehicles are required to understand these exercises as controlling the earth and for improvement.

Also, According to the results it appeared that in the course of the most recent years Technology Entrepreneurship has created as a particular stream of research at the nexus of Entrepreneurship and the Management of Technology and Innovation. However, in spite of a few unique issues and an expanded level of intrigue, no exhaustive meaning of the field has been created up until now. The same results appeared with a study by Sajjad et al, (2012) who argued that innovation enterprise lies at the core of numerous essential level headed discussions, including those around propelling and developing firms, local financial improvement, choosing the proper partners to take thoughts to business sectors, and instructing directors, engineers, and researchers. Unless a for the most part acknowledged meaning of innovation business is set up, in any case, these verbal confrontations lose their core interest. The author contends that innovation business enterprise is an interest in a venture that amasses furthermore, conveys particular people and heterogeneous advantages for make and catch esteem for the firm. What recognizes innovation enterprise from other enterprise writes (e.g., social business enterprise, private company administration, and independent work) is the community oriented experimentation and generation of new items, resources, and their characteristics, which are unpredictably identified with propels in logical and innovative information and the company's advantage proprietorship rights.

Among the variables which appeared to be influential on the idea of Entrepreneurship Initiatives is the culture. The issue of culture has been the sponsor of any talks that are related to Entrepreneurship Initiatives. As of late a developing attention to the significance of entrepreneurial movement for monetary improvement has activated research on the essentials of business enterprise. Cross-national contrasts in levels of entrepreneurial movement might be clarified by an extensive variety of monetary, innovative, social and institutional elements. Specifically, contrasts in esteem frameworks and social introductions towards business enterprise have been contended to influence business enterprise. Culture has assumed an expanding part in statistic clarifications more than two past decades. For understanding the inspiration of business enterprise conduct, it is important to have some information of its properties with respect to comprehension the setting in which conduct happens, having some learning of its properties is vital. According to Bailetti (2012) In the monetary folklore of the industrialized West, the business visionary is viewed as a free, hazard taking nonconformist who strongly composes the general population and assets essential for making new business wanders. For such a part to rise inside a culture, no less than two social conditions must exist: (1) business visionaries must be conceded social acknowledgment so the exercises related with new pursuit arrangement are acknowledged as authentic and socially useful, and, (2) business visionaries must have the capacity to access and control of money related, material and instructive assets important to start new pursuits. Condition one requires that the entrepreneurial part be approved by an arrangement of social esteems that perceives the authenticity of the entrepreneurial capacity; condition two requires social establishments and methods that give potential business visionaries access to fundamental assets.

\section{Conclusion and Recommendations}

The current study aimed at understanding the influence of the Arabic Entrepreneurship Initiatives on creativity and innovation in business within telecommunication companies in Jordan. It was hypothesized that the dimensions of entrepreneurship including (Strategies, Technology, Resources, Management Support and Culture) positively influences the creativity and innovation of business within the Arabic environment. The sample of the study was derived from a telecommunication companies which included (34) individuals from the high and the middle management.

The results of the study indicated that there is a positive influence of entrepreneurship initiatives on creativity and innovation within organizations and enterprises. The most influential variables appeared to be (Culture, Management Support, Technology, Strategies and Resources) respectively. The most influential variable appeared to be the culture. In other meaning; the culture are one of the most important factors that really 
influences the degree of innovation and creativity within the entrepreneurship initiatives. However, Western style of business will probably develop inside societies that express esteems identified with: (a) low power remove, (b) low vulnerability shirking, (c) high independence, and, (d) manliness. A survey of nation scores in Hofstede's investigation shows that this profile intently fits the U.S. also, a few industrialized AngloSaxon countries (e.g. Incredible Britain, Canada and Australia). This should come as no amaze since business as we right now know it in Western models found its first articulation in England and later blossomed in the social setting of North America. On the off chance that culture supplies the underlying social conditions under which entrepreneurial practices rise, at that point the practices and practices that constitute current ideas of business ought to be relied upon to fit the estimations of the societies that created and molded the marvel. Social esteems and convictions make a "psychological programming" among society individuals that is utilized to assess social practices, for example, business enterprise. The psychological programming present in a few Anglo nations appears to help a style of business enterprise in light of individual innovativeness and activity. It has made a social setting where entrepreneurial open doors are across the board and accessible to numerous and where entrepreneurial achievement is remunerated both physically and mentally. Can a comparable social setting be reproduced, be that as it may, in countries that don't have an indistinguishable mental programming and qualities from the Anglo-Saxon West? Do countries with disparate esteems need to experience an burdensome procedure of social change before entrepreneurial practices can be effectively exchanged or are there elective models of business enterprise that may serve to accomplish the monetary objectives of expanded wage, business and advancement in creating countries? In spite of the fact that the business visionary as rough nonconformist might be an exciting picture in individualistic social orders, it might be an unsavory one in collectivist societies where individual character is gotten fundamentally from amass enrollment and cooperative choice attempting is liked to individualistic endeavors. In a general public where gathering enrollment and acknowledgment overshadow singular contemplation, it is dubious that a style of business enterprise in view of individual activity will take root. There is no financial law, notwithstanding, that requires new organizations to be shaped by people. In collectivist societies, types of enterprise in light of gatherings may substitute for singular activity.

Based on the results of the study and the above argument, the author recommends the following:

1- Nourish the culture within the Arabic business environment in a way that makes more welcoming to any Entrepreneurship Initiatives

2- Train the coming management individuals to be supportive of any Entrepreneurship Initiatives and increase their awareness on the importance of Entrepreneurship.

3- Involve technology in all aspects of business and on a well-built base so that the coming generations would find the tools and the space to be more productive.

\section{References}

Audretsch, D. (2004). Sustaining Innovation and Growth: Public Policy Support for Entrepreneurship. Industry and Innovation, 11(3), 167-191.

Baer, M., \& Frese, M. (2003). Innovation is not enough: Climates for initiation and psychological safety, process innovations, and firm performance. Journal of Organizational Behavior, 24(1), 45-68.

Bailetti, T. (2012). Technology entrepreneurship: overview, definition, and distinctive aspects. Technology Innovation Management Review, 2(2), 5.

Bridge, S. (2017). Is "entrepreneurship" the problem in entrepreneurship education? Education + Training, 59(7/8), 740-750.

Bryman, A., \& Bell, E. (2003). Business Research Methods. Social Research, 792.

Coster, C. (2004). Capital and Innovation How Britain Became the First Industrial Nation. Northwich: Arley Hall Press.

Dess, G. (2003). Emerging Issues in Corporate Entrepreneurship. Journal of Management, 29(3), 351-378.

Different Perspectives of an Emerging Concept. Entrep. Theory Pract., 33(1), 1-17.

Gaddefors, J., \& Anderson, A. (2017). Entrepreneursheep and context: When entrepreneurship is greater than entrepreneurs. International Journal of Entrepreneurial Behavior \& Research, 23(2), 267-278.

Gurel, E., Altinay, L., \& Daniele, R. (2010). Tourism student's entrepreneurial intentions. Annals of Tourism Research, 37(3), 646-669.

House R. J., Quigley N. R., \& De Luque M. S. (2010). Insights from Project GLOBE Extending global 
advertising research through a contemporary framework. International Journal of Advertising, 29(1), 111-139.

Hunt, S., \& Levie, J. (2003). Culture as a predictor of entrepreneurial activity. En W. D. Bygrave (Ed.), Frontiers of entrepreneurship research 2003 (171-185). Wellesley, MA: Babson College.

Hunter, S. T., Bedell, K. E., \& Mumford, M. D. (2007). Climate for Creativity: A Quantitative Review. Creativity Research Journal, 19(1), 69-90.

Karlsson, C., Friis, C., \& Paulsson, T. (2004). Relating entrepreneurship to economic growth. CESIS/JIBS Electronic Working Paper Series.

Klein, P. (2008). Opportunity Discovery, Entrepreneurial Action, and Economic Organization. Strateg. Entrep. J., 2, 175-190.

Kurato, D. F., \& Hodgetts, R. M. (2007). Entrepreneurship Canada: The Thomson Corporation.

Lazear, E. P. (2005). Entrepreneurship. J. Labor Econ, 23, 649-680.

Lim, D. S. K., Morse, E. A., Mitchell, R. K., \& Seawright, K. K. (2010). Institutional environment and entrepreneurial cognitions: A comparative business systems perspective. Entrepreneurship theory and Practice, 34(3), 491-516.

Low, M. B. (2001). The adolescence of entrepreneurship research: specification of purpose. Entrepreneurship Theory and Practice, 25(4), 17-25.

Martin, R., \& Osberg, S. (2007). Social Entrepreneurship: The Case for Definition. Stan. Soc. Innov. Rev, 29-39.

Mcbeth, E.W., \& Rimac, T. (2004). The Age of Entrepreneurial Turbulence, Creating Sustainable Advantage for Individuals, Organizations and Societies in the New Century ESADE MBA BUSINESS REVIEW.

Nnadi, C. (2014). The Role of Creativity and Innovation in Business Growth and Sustainability: An Ideal Model. Int $J$ Econ and Manage Sci, 3,171. https://doi.org/10.4172/2162-6359.1000171

Padilla, A., \& Cachanosky, N. (2016). Indirectly productive entrepreneurship. Journal of Entrepreneurship and Public Policy, 5(2), 161-175.

Rahatullah Khan, M. (2013). Mapping entrepreneurship ecosystem of Saudi Arabia. World Journal of Entrepreneurship, Management and Sustainable Development, 9(1), 28-54.

Sajjad, S.I., Shafi, H. and Dad, A.M., 2012. Impact of culture on entrepreneur intention. Information Management and Business Review, 4(1), p.30

Sumo, R. (2010). Corporate entrepreneurship: Using organizational structure elements.

Taylor, D. (2007). Entrepreneurship and Small Business (2nd ed.). Burns P.. Basingstoke: Palgrave Macmillan.

Uslu, T. (2015). Innovation culture and strategic human resource management in public and private sector within the framework of employee ownership. Procedia-Social and Behavioral Sciences, 195, 1463-1470.

\section{Copyrights}

Copyright for this article is retained by the author(s), with first publication rights granted to the journal.

This is an open-access article distributed under the terms and conditions of the Creative Commons Attribution license (http://creativecommons.org/licenses/by/4.0/). 